\title{
LETTER
}

\section{A chat with the 2021 class freshmen}

Dear freshmen,

$I^{2}$ was admitted at Rio Grande do Sul Federal University's Faculty of Medicine in 1956. In that year, Brazil had 24 medicine schools and the one in Porto Alegre, founded in 1898, was Brazil's third. When I graduated in 1961, this number had increased to 33 - nine more - and except four of them, all were public institutions.

You are starting your studies this year and the information I have is that by December 2015 there were 266 medical courses, most of them private. When you graduate, only God knows how many schools there will be. However, considering the intentions of this misgovernment and the list of demands, I bet there will be more than 300. Most of the ones that already exist do not have the minimum requirements for training physicians; they are precarious institutions and will grant diplomas to unqualified citizens. This is terrible, because there is an old proverb that goes by: having a bad doctor is worse than not having any. Yes, because the healing power of Nature is gargantuan and those professionals who are unprepared and lack common sense damage its healing force. In a morning lost in the vertigo of my life, the inaugural lecture was about the Hippocratic concepts vis medicatrix Naturae and primum non nocere, but as I said, this was very long ago. If you wish to learn more about these teachings of Hippocrates just ask master Google; for now it is enough to inform you that currently, the diseases resulting from medical treatment and medical malpractice present incidences as frightening as cancer, and cardiac and cerebral infarctions.

The "More Doctors" (Mais Médicos) program is not appropriate for promoting health. Your curriculum, my dear freshmen, was devised for professionals who intend to treat patients. Eighty percent of what shall be required from you during your studies are connected to diseases and the people affected by them.

Seen from the Health stage, the doctor is a supporting artist and not the main actor. The preservation of health requires many actions based on Education, Engineering, Economics and so many other non-medical professional skills. The university courses which are nearest to all this are the Public Health schools and there is one, a very well-respected one, which is a neighbor to your school. It would have been much better if the Government had been interested in increasing the number of these professionals while wishing the best to our health.

This vast number of medical courses has a lot to do with you. Many of your colleagues graduating in these schools scattered throughout Brazil will knock on Hospital das Clínicas door seeking improvement and mainly Medical Residency, because where they graduated there is none. In my school there was still no Medical Residency and we had to face life as soon as we got our diplomas. Definitely, this will not be your case. Just ask your senior colleagues and Hospital das Clínicas medical residents, they know quite well that at the end of six years the medical school diploma does not qualify anyone to practice the profession. Medical Residency is, so to speak, a compulsory complement to the undergraduate studies and even after its completion one or more years of specialization are required for many professional activities. It so happens that the number of vacancies available in Medical Residencies is limited and there is a new 'entrance exam' to be faced with many competitors. This is awful, I am totally against it, and it points towards the failure of the educational system: all those who entered the medical courses and completed 
them satisfactorily should be accommodate in Residency. However, it is not so and I suspect that in 2021, it will be much worse and you will have to submit to the rules which are effective then. My best advice: fight for your rights.

And here I would like to draw your attention to something that I have been observing and leaves me very concerned.

Many students slow down after surpassing the entrance exam hurdle to our Medical School, the famous Casa de Arnaldo. Several reasons contribute to this behavior: disappointment with some basic subjects lectured in the first years, absence of sound guidance for learning, lack of medical professional motivation, and others. Allow me to make a brief remark here: during the first year, sixty years ago, not only did I see many patients, but also watched surgeries and helped in an anesthesia procedure holding the Ombredanne inhaler; during the second year, naturally 'aided' by a surgeon, I performed an appendectomy. Nowadays, this is out of question, your involvement with patients will be much less. Later on, the awareness of the importance of residency to be a professional greatly diminishes the urgency of learning during the course, and the preparation to conquer a vacancy seriously hinders the internship offered in the last two years.

The most important advice I can give you is to take the initiative during the course and learn by yourself. Do not expect that the teaching shall make yourselves doctors. The Medical School will not qualify you; it is up to you to use it for your professionalization.

This year, Casa de Arnaldo is struggling to improve its curriculum. This is good; however, it will still take time for the two most important things to be implemented: specific behavioral goals and formative evaluations of all subjects. Currently, few courses state the behavioral changes expected from the student in consequence to the teaching process they offer. If asked, most teachers will say in general terms that you should know this and that, but they do not go into details that would really allow you to study on your own.

There are also no tools to evaluate your own knowledge. This educational tool is essential and should be available like DETRAN (Brazilian State Traffic Department) qualification tests that populate the internet.
If this is all Greek to you and you want to read something about behavioral goals and formative evaluation, refer to the Estação Digital Médica (Medical Digital Station) website of FMUSP Telemedicine course. In the opening page, you will find the CONHEÇA (Learn More) chart, look for Avaliação do Rendimento Educacional (Educational Performance Evaluation) and click on it. On pages 21 to 27 you will find behavioral goals, and on pages 107 to 112 , formative evaluation.

On the Internet there are behavioral goals and formative assessments of the subjects you are taking, especially from foreign universities, in English. Use them, try and form study groups and do not be afraid to learn subjects taught outside the scope of your medical course. Incidentally, those of you who do not have command of the English Language must learn it urgently. If necessary, miss a year of your course but do not graduate without such competence.

I would recommend you to read Atul Gawande's book in these days of euphoria brought by the triumph in the entrance exams. He is a surgeon at Harvard, worried with the exercise of his profession. The original title is Being Mortal, edited in Portuguese as Mortais. A splendid work, which is easy to read, and stresses the importance of the patient in these times when hospitals value more diseases than patients. Each specialist treats one aspect of the illness and forgets the patient as a person. Dr. Atul's parents are Indian; his father, who was also a doctor, died of a rare disease which he followed up with filial love and which encouraged him to write the book. He insists on the fact that physicians treat mortal beings, that is, they must be prepared to deal with death as well. This was obvious a few decades ago, but nowadays it has become increasingly distant from the concerns of physicians, the efforts are focused on maintaining life at all costs.

This issue is serious and there is a reaction against the negligence with which patients are treated. You will hear a lot about the need for humanization in Medicine. I confess I do not like this word and I do not even know exactly when the animalization of our art began, but in the $80 \mathrm{~s}$, a picturesque episode occurred that attests that the concern already rooted among us regarding the lack of compassion for the ill. Since it was never published, or at 
least so I believe, I will narrate this incident in a few words.

A Surgery Congress was held at the HC-FMUSP Rebouças Convention Center and it had a panel on "The surgeon before incurable diseases". For this purpose they invited one or two surgeons, I cannot remember exactly, the esoteric psychiatrist Elisabeth Kübler-Ross, who is a specialist in terminal processes, and Jorge Luis Borges. The Argentinean writer, who was sick, apologized for not attending the Congress and sent his contribution in writing. He was replaced on the panel and his considerations were not presented due to the prudishness of that time: it contained a swear word. I read his letter with a friend and found it splendid, precisely because of this most fortuitous dirty word.

Borges, with his unparalleled verve, tells how the death of his grandmothers happened. The first lady, of English descent, spent her last days surrounded by doctors and nurses, with daily hygienic care, administration of serums and intravenous injections according to the prescriptions, gavage feeding and, of course, urethral sounding. She endured it all with stoic fortitude, without complaint, until she departed in a beautiful autumn afternoon, muttering prayers between nearly closed lips.

The time came for the other grandma, who was a Creole from the Pampas. The family felt equally appalled and redoubled the measures so that she lacked nothing that modern medicine could offer. After four days of intensive care, the visibly angry old lady hissed in a weak voice:

"!Pero dejen me morir tranquilla, carajo!" (something like "Just leave me the fuck alone to die!")

Did Borges leave any doubt regarding what a surgeon should do in incurable cases?

It is almost certain that you, my dear freshmen, shall visit Hospital das Clínicas ambulatory or health centers, in other words places where patients seek medical assistance. I do not know what your feelings will be, but they may be those of sadness.

Sadness for the defrauded hope of quite a few people. A minority is really sick and seeks SUS (Sistema Único de Saúde - Unified Health System) for treatment. We must recognize that it leaves much to be desired. The well-known concept that "health is every citizen's right and the State's duty" sounds more like a bad joke than a law to be fulfilled. The reality is that the price of Medicine is so exorbitant that the State will never fulfill its legal obligation. Nothing in the past decades got as expensive as treating serious diseases.

Sadness to feel the poverty, ignorance and conformism of the crowd that uselessly submits to the ritual of appointments. Most of them are unnecessary and steal time and resources from those who already have so little. Medicine, the system and its agents, succeeded in the Twentieth Century to turn the demand for doctors and the consumption of drugs into an addiction, to use a strong word. A high percentage - I would say 80 per cent or more - of the appointments are dispensable, and of the drugs, useless when not harmful.

To wave away the sadness I recommend reading "Il malate immaginato", by the Italian cardiologist Marco Bobbio; its version in Portuguese, named $O$ doente imaginado (The imagined ill), is prefaced by my colleague Dario Birolini, retired from Casa de Arnaldo and still one of the most skilled surgeons in the city. Imagined, yes sir, there are many imagined ill people.

Dear youngsters, sixty years exactly separate our courses, almost an eternity. I am probably not wrong when I say that my class was closer to Hippocrates's students than to you. I know he did not have any idea of the cell and we were taught that it was a biological unit with a membrane, cytoplasm, nucleus, nucleolus and Golgi apparatus. The most interested of us had notions of the first electron microscopy discoveries, found in magazines that were hard to access and whose contents had not yet penetrated the standard teaching. Rest assured that no matter how much we tried we still knew less about the cell than any high school student does nowadays. However, the information surrounding us was infinitely smaller than the information that surrounds you. It is true that all the existing knowledge from the dawn of humanity until 2003 is almost negligible if compared to the amount added in the last twelve years.

You should know that three discoveries dramatically changed the way humans think: writing, numbers and digitalization, a name some give to this revolution we live in, of a violence and speed never imagined before. You were born in the three of them but I was not. Think about it. I started studying when the mystery surrounding the Golgi 
apparatus was lifted and you when the six billion human genome bases were sequenced. There is some difference, isn't there? We saw the future that awaited us at the end of those six years and the deviations were nothing but details. You, who belong to the native digital generation, what kind of Medicine can you see awaiting you in 2021? If you do not know, check the little device that communicates voice and writing, hears and sees, has access to an amount of information beyond imagination and has countless applications. What does it foretell about the profession you have chosen? Nothing, I guess.

I also do not know, and I dare only to suppose that Brazil will be halfway between its current reality and a future in progress in more advanced countries, beyond my horizon, but not beyond yours. It is my belief - and the belief of many others - that the Medicine practiced nowadays will be almost unrecognizable, precisely due to the power of the gadget that inhabits most of human beings' pockets. Our art has a rigid nature, resistant to change and has been very little touched by digitalization, but the inevitable will come in the forthcoming years and the changes will be as drastic as they were in the financial world. If you wish to read something about medical futurology I have a wonderful work to suggest: The creative destruction of Medicine, by Eric Topol, cardiologist, geneticist and researcher on the field of digital medicine. I think it has not been translated yet; however, check it on your phones because I might be wrong.

Enjoy your reading,

György Miklós Böhm Professor Emeritus of São Paulo University's Faculty of Medicine 